\title{
Analysis of Local Expenditure Determinants in Districts/ Cities in the East Java Province
}

\author{
Hapsari Nur Aziza, Mahendro Sumardjo
}

\begin{abstract}
This study aims to test the effect of local ownsource revenue, general allocation fund, special allocation fund, and population amount towards local expenditure. This study used all 39 districts/cities in the East Java Province as samples. The sample collection method used in this study is the saturated sample method. This study uses secondary data from the budget realization report and population. The analysis method used is the double linear regression method using SPSS with a significance rate of $5 \%(0.05)$. The result of this study shows that local own-source revenue, general allocation fund, and population amount has a significant effect towards local expenditure. Meanwhile the special allocation fund partially does not have a significant effect towards local expenditure. This contribution for the local government of the East Java Province is hoped to be able to provide information to the people regarding the importance of paying taxes, since the payment of taxes will increase the region's local own-source revenue, and in turn promote the people's welfare.
\end{abstract}

Index Terms - Local Revenue, General Allocation Fund, Special Allocation Fund, Population, Local Expenditure.

\section{INTRODUCTION}

Local Expenditure in the Local Government Budget in provincial governments in Indonesia has not received adequate attention. The allocation of Local Expenditure is not yet efficient and has not been executed well enough to promote the people's welfare, since the management of Local Expenditure is not yet public-oriented. One of the factors that cause this is the disruption of certain groups. Local governments should be able to allocate more towards Local Expenditure, so that the funds are not solely used for employee expenditures and routine expenditures [9].

In order to develop the potentials of a region, region autonomy is implemented. Region autonomy is implemented in hopes that roles, authorities, and responsibilities will increase towards the improvement of public services and local development. With this autonomy, decentralization is executed, as a consequence from the delegation of authority, followed by the authority to use the budget and execute those authorities. With the implementation of region autonomy, the government must of course increase the budget for local expenditure.

According to Law Number 23 Year 2014 on the Local Government, Local Expenditure is all liabilities of the region that are recognized as a deduction of net wealth in the relevant budget year. Local expenditure is used to fund the execution of governmental affairs, which have become the authority of

Published on July 22, 2020

Hapsari Nur Aziza, Universitas Pembangunan Nasional Veteran Jakarta, Indonesia.

(e-mail: hapsari.nur@upnvj.ac.id). the Province or the District/City which consists of mandatory affairs, voluntary affairs, and affairs in which the handling in a certain department can be executed jointly between the Central Government and the Local Government, or between Local Governments, that have been set by legal regulations. Local Expenditure is categorized into indirect expenditure and direct expenditure. Indirect expenditure consists of budgeted expenditures that are not directly related to the execution of programs and activities. Meanwhile, direct expenditures are budgeted expenditures that are directly related to the execution of programs and activities.

Optimal Local Expenditure is expected to be able to increase the quality of public services to satisfy the people towards governmental service. If the people are satisfied, it is expected that they will contribute by paying taxes, which will increase Local Own-Source Revenue (PAD). The General Allocation Fund (DAU) is the fund allocated to balance the competencies of the region. However, at present, the DAU is mostly used for Local Expenditure purposes. Expenditure needs that should use the PAD, uses the DAU instead. The Special Allocation Fund (SAF) is also one of the determinant factors for local expenditures. Aside from that, the population is also one of the determinant factors of the realization of Local Expenditure that will be allocated. Therefore, to improve the quality of public services, local governments should increase Local Expenditure allocation by increasing sources of local revenue, which influences local governments in allocating Local Expenditure, as well as to align expenditure realization with the population amount in the respective region.

The aforementioned phenomenon, in order to strengthen the effect of Local Expenditure, the researches will conduct other studies, however, using several indicators that have been previously researched. However, there are inconsistencies in previous studies, such as the research by [24], and [8], that states that Local Own-Source Revenue has an effect towards Local Expenditure. On the other hand, studies conducted by [13], [10], [26], state the opposite. The studies by [14] and [1] state that the General Allocation Fund has an effect towards Local Expenditure. Meanwhile, the studies conducted by [18] and [13] state the opposite. Further, the study conducted by [12] and [14] state that the Special Allocation Fund has an effect towards Local Expenditure. On the other hand, the studies conducted by [25] and [6], state the opposite. Lastly, the study conducted by [23] as well as [21], state that population amount has an effect towards Local Expenditure. However, the study conducted by [13], states

Mahendro Sumardjo, Universitas Pembangunan Nasional Veteran Jakarta, Indonesia.

(e-mail: mahendro@upnvj.ac.id) 
the opposite. This study aims to test the effect of Local OwnSource Revenue, General Allocation Fund, Special Allocation Fund, and Population Amount towards Local Expenditure.

\section{LITERATURE REVIEW}

\section{A. Stakeholder Theory}

The background of the stakeholder theory is the desire to build a responsive framework towards problems faced by managers, which include environment changes. [6] and [20] briefly defines the stakeholder as a person with an interest or focus towards a specific issue. A related study that uses the stakeholder theory as a theoretical basis to study the effect of local own-source revenue towards local expenditure was conducted by [8]. The relationship between this study and the stakeholder theory is that the local government, in realizing local expenditure, must take into consideration the interest of the people, since they also contribute towards it through funding local needs by utilizing sources of local potential, such as paying taxes. Furthermore, the aim of local governments in realizing local expenditure is to promote the people's welfare, which should be the main agenda that must be taken into account.

\section{B. Agency Theory}

The agency theory states that the agency relationship is the agreement (contract) between 2 (two) parties, which are the principal and the agent, in which the principal delegates a degree of authority and trust towards the agent to make decisions on behalf of the principal. In the public sector agency theory, the relationship involves 3 (three) parties, which are the principal, agent, and auditor. Related studies that utilizes the agency theory as a theoretical basis to study the effects of the General Allocation Fund, Special Allocation Fund, and Population amount towards Local Expenditure was conducted by [25], [15], as well as [6]. The relationship between this study and the agency theory is that the local government is given trust by the people in managing funds transferred by the central government on behalf of the people, in which those regulations must fulfill the needs of the people.

\section{HYPOTHESIS DEVELOPMENT AND CONCEPTUAL SCHEME}

Local Own-Source Revenue is used as an instrument to optimize sources of local wealth, which is used by local governments with the aim of executing its authorities in executing regional autonomy [3]. Studies conducted by [7], [13], as well as [18] tests the effects of local own-source revenue towards local expenditure. Previous studies show that local own-source revenue has a significant effect towards local expenditure. Based on this explanation, the following hypothesis is formulated:

$\mathrm{H}_{1}$ : Local own-source revenue has a significant effect towards Local Expenditure.

The General Allocation Fund is a fund transferred by the central government to local governments in order to realize local expenditure which is utilized for infrastructure development, and therefore creates inter-regional balance and decreases fiscal discrepancies between regions. A study conducted by [16],[22], as well as [2] tests the effect of the General Allocation Fund towards Local Expenditure. The result of previous studies show that the General Allocation Fund has a significant effect towards Local Expenditure. Based on the explanation above, the following hypothesis is formulated:

$\mathrm{H}_{2}$ : The General Allocation Fund has a significant effect towards Local Expenditure.

The Special Allocation Fund is a fund of the local government that is sourced from balancing funds allocated to specific regions to aid them in funding the physical needs of the facilities and basic infrastructure, which is the national priority in the sectors of education, health, infrastructure, marine and fisheries, local government infrastructure, and environment [7]. A study conducted by [15], [12], and [14] tested the effect of the Special Allocation Fund towards Local Expenditure. The result of previous studies show that the Special Allocation Fund has an effect towards Local Expenditure. Based on this explanation, the following hypothesis is formulated.

$\mathrm{H}_{3}$ : The Special Allocation Fund has a significant effect towards Local Expenditure.

A large population is viewed by local governments as an asset and development expense, in which a large population will demand an increase in local expenditure, aimed to promote the people's welfare in regards to facilities and infrastructure, as well as public services. A study conducted by [24], [21], and [11] tests the effect of population amount towards local expenditure. Previous studies show that Population Amount has a significant effect towards Local Expenditure. Based on this explanation, the following hypothesis is formulated:

$\mathrm{H}_{4}$ : Population Amount has a significant effect towards Local Expenditure.

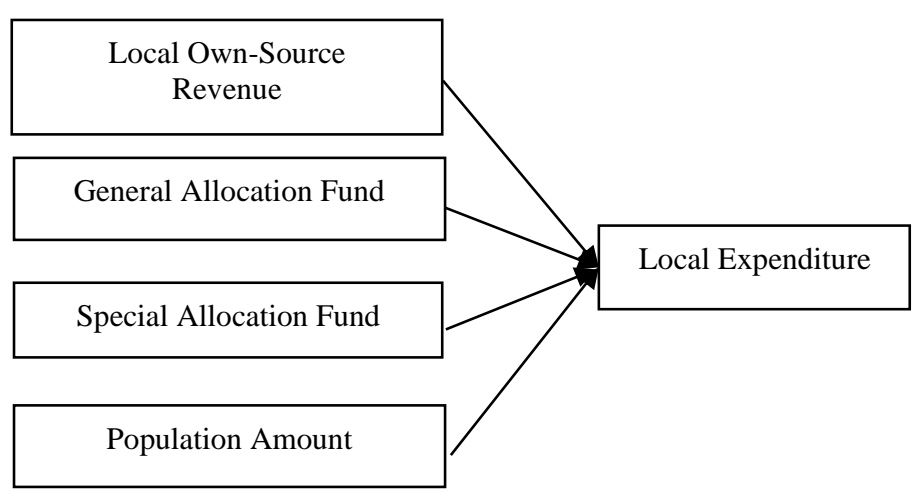

\section{RESEARCH METHODOLOGY}

The research methodology used in this study is secondary data from the Budget Realization Report and Population Projection in the East Java Province in the years 2016-2018. The samples used in this study are 78 samples from a total of 117 samples that were studied. This research used the double linear regression hypothesis in the SPSS application. The dependent variable, which is Local Expenditure was measured using indicators adopted from the study conducted by [8]. The independent variable, Local Own-Source 
Revenue, was measured based on indicators from the study conducted by [3] and [4]. The General Allocation Fund and Special Allocation Fund was measured using indicators adopted from the study conducted by [8], while the Population Amount variable was measured using indicators adopted from the study conducted by [24]. This study uses the ratio scale.

\section{RESULTS AND DISCUSSION}

\section{A. Descriptive Analysis}

Based on the saturated sampling method, 117 samples from 39 districts/cities for a period of 3 years were retrieved. However, upon outlier data elimination, only 78 samples were used in this study. The independent variable, Local Own-Source Revenue, had an average value of 26.49 , the General Allocation Fund had an average value of 27.65, the Special Allocation Fund had an average value of 26.45 and the Population Amount had an average value of 6.01 . Meanwhile, the variable dependent, Local Expenditure, had an average value of 28.26 .

TABLE I: RESULTS OF DESCRIPTIVE STATISTICS

\begin{tabular}{cccccc}
\hline Variable & N & Min & Max & Mean & SD \\
\hline LR & 78 & 25,63 & 28,14 & 26,4942 &, 52804 \\
GAF & 78 & 27,13 & 28,17 & 27,6495 &, 21124 \\
SAF & 78 & 25,44 & 27,04 & 26,4554 &, 27214 \\
P & 78 & 5,45 & 6,41 & 6,0095 &, 19111 \\
LE & 78 & 27,84 & 28,80 & 28,2578 &, 24262 \\
Valid N & 78 & & & & \\
\hline
\end{tabular}

\section{B. Results}

The results of the hypothesis testing of this study can be seen in Table 2.

TABLE II: TESTING OF HyPOTHESIS OF DESCRIPTIVE STATISTICS

\begin{tabular}{lrr}
\hline \multicolumn{1}{c}{ Model } & Coefficients' & \\
\hline 1 (Constant) & \multicolumn{1}{c}{ t } & Sig. \\
LR & 3,300 &, 001 \\
GAF & 10,151 &, 000 \\
SAF & 5,077 &, 000 \\
P &, 772 &, 443 \\
\end{tabular}

The data processing result of this study showed that Local Own-Source Revenue has a $t_{\text {calculated }}>t_{\text {table }}$ value of $10.151>$ 1.993 with a significance value of $0.000<0.05$, which means that Local Own-Source Revenue has a significant effect towards Local Expenditure. Therefore, it can be concluded that Local Own-Source Revenue has a significant effect towards Local Expenditure. The result of this study is in line with the study conducted by [8], which stated that Local Own-Source Revenue has a significant effect towards Local Expenditure. The result of this study is also in line with the stakeholder theory, in which the local government must prioritize the interest of the people, who contribute in the realization of Local Expenditure in funding local needs by paying taxes, which are a component of Local Own-Source DOI: http://dx.doi.org/10.24018/ejbmr.2020.5.4.389
Revenue. Furthermore, the aim of local governments in realizing Local Expenditure is to promote the people's welfare, which must be their main focus.

The data processing result of this study shows that the General Allocation Fund has a $t_{\text {calculated }}>t_{\text {table }}$ value of 5.077 $>1.993$ with a significance value of $0.000<0.05$, which means that the General Allocation Fund has a significant effect towards Local Expenditure. Therefore, it can be concluded that the General Allocation Fund has a significant effect towards Local Expenditure. The result of this study is in line with the study conducted by [25], which stated that the General Allocation Fund has a significant effect towards Local Expenditure. The result of this study is also in line with the agency theory, in which local governments are given trust by the people (represented by the National, Regional, and District House of Representatives) in managing the General Allocation Fund, which is transferred by the Central Government to realize Local Expenditure in the form of infrastructure building, to increase local capacity in promoting the welfare of the people, achieving equal regional distribution, and decrease financial discrepancies caused due to local needs that are larger than the potential of the region itself.

The data processing result of this study shows that the Special Allocation Fund has a $\mathrm{t}_{\text {calculated }}<\mathrm{t}_{\text {table }}$ value of 0.772 $<1.993$ with a significance value of $0.443>0.05$, which means that the Special Allocation Fund does not have a significant effect towards Local Expenditure. Therefore, it can be concluded that the Special Allocation Fund does not have a significant effect towards Local Expenditure, and the proposed hypothesis is rejected. The result of this study is not in line with the study conducted by [14], and is instead in line with the study conducted by [24], which states that the Special Allocation Fund does not have a significant effect towards Local Expenditure. In this study, the proposed hypothesis is rejected and does not support the agency theory which states that local governments are given the authority to execute proper management of finances. The use of the Special Allocation Fund has been determined by the Central Government, and therefore, the Local Government does not have the authority to utilize and manage those funds. Furthermore, the Special Allocation itself has a relatively smaller amount, since it is solely aimed to fund activities that are only of national priority, and therefore local needs are difficult to predict.

The data processing result of this study shows that Population Amount has a $t_{\text {calculated }}>t_{\text {table }}$ value of $2.183>$ 1.993 with a significance value of $0.032<0.05$, which means that Population Amount has a significant effect towards Local Expenditure. Therefore, it can be concluded that Population Amount has a significant effect towards Local Expenditure. Therefore, it can be concluded that Population Amount has a significant effect towards Local Expenditure. This study is in line with the agency theory, in which the principal, represented by the National/Local/District House of Representatives act to monitor the agent, the Local Government's performance. The agent (local governments), and the principal (represented by the National/Local/District House of Representatives, must be fully aware of what is needed by the people, in regards to both quantity and quality aspects. The larger the population in the region, the more Vol 5 | Issue 4 | July 2020 
needs must be fulfilled. Therefore, information on the Population Amount is vital, since local governments must create policies that can fulfill the needs of all of the people.

\section{CONCLUSiOn, Limitations And RECOMMENDATIONS}

Local own-source revenue has a significant effect towards local expenditure. This shows that an increase or decrease in local own-source revenue proportionally affects the realization of local expenditure. The general allocation fund has a significant effect towards local expenditure. This shows that an increase or decrease in the general allocation fund proportionally affects the realization of local expenditure. The special allocation fund does not have a significant effect towards local expenditure. This shows that an increase or decrease in the special allocation fund does not proportionally affect the realization of local expenditure, and inversely affects it instead. This is due to the fact that the use of the special allocation fund is regulated by the Central Government, and therefore, the Local Government does not have the authority to manage and use those funds, and the needs of the region are difficult to predict. The Population Amount has a significant effect towards Local Expenditure. This shows that an increase or decrease in Population Amount proportionally affects the realization of Local Expenditure.

The recommendation of this study for the East Java Province Local Government is that it is hoped to be able to provide information to the people on the importance of paying taxes, since the payment of taxes will increase the region's Local Own-Source Revenue, which aims to promote the welfare of the people. Furthermore, the next researcher is hoped to be able to use other variables that have not been used in this study, such as tax sharing and region size, as well as studying other regions that have not yet been studied.

\section{REFERENCES}

[1]. Abdillah, K., \& Mursinto, D. (2016). The Effects of Financial Balance Transfer and Regional Own-Source Revenue on Regional Expenditure of Regencies and Municipalities in East Java Province. International Journal of Scientific and Research Publications, 6(5), 26-30.

[2]. Asih, S., \& Irawan. (2018). Pengaruh Kontribusi Pajak Daerah, Pendapatan Asli Daerah, Retribusi Daerah Dan Dana Bagi Hasil Pajak Terhadap Belanja Daerah Dengan Pertumbuhan Ekonomi Sebagai Variabel Moderating Pemerintah Kabupaten Dan Kota. Jurnal Akuntansi Bisnis \& Publik, 9(1), 177-191.

[3]. Aswar, K. (2019). Financial Performance of Local Governments in Indonesia. European Journal of Business and Management Research, $4(6), 1-6$.

[4]. Aswar, K., \& Surbakti, L. P. (2013). Pengaruh desentralisasi fiskal terhadap pendapatan asli daerah dan belanja publik kabupaten/kota di Indonesia. Proceeding PESAT, 5 Oktober, 161-169

[5]. Biset, "Personal Communication", http://sondix.blogspot.com/2013/08/pengertianstakeholder.html?m=1 (Diakses tanggal 10 Mei 2020)

[6]. Dewi, K. R., Kepramareni, P., \& Novitasari, N. L. G. (2017). Pengaruh Pendapatan Asli Daerah (PAD), Dana Alokasi Umum (DAU), Dana Alokasi Khusus (DAK) Dan Dana Bagi Hasil (DBH) Terhadap Alokasi Belanja Daerah Kabupaten/Kota Se-Bali. Jurnal Riset Akuntansi JUARA, 7(1), 180-188.

[7]. Ermawati, \& Aswar, K. (2020). Assessing regional finance independence in Indonesian local governments. European Journal of Business and Management Research, 5(1), 1-5.

[8]. Fatimah, N. N., Nopiyanti, A., \& Mintoyuwono, D. (2019). Pengaruh Pendaptan Asli Daerah Dan Dana Perimbangan Terhadap Belanja Daerah. Equity, 21(1), 1-16.

DOI: http://dx.doi.org/10.24018/ejbmr.2020.5.4.389
[9]. Felix, O. (2012). Analysis of the effectiveness of capital expenditure budgeting in the local government system of Ondo State, Nigeria. Journal of Accounting and Taxation, 4(1), 1-6.

[10]. Fuad, \& Zakaria. (2015). Pengaruh Dana Alokasi Umum Dan Pendapatan Asli Daerah Terhadap Belanja Daerah. Jurnal Future, 134-144.

[11]. Gorahe, I. A. M., Masinambow, V., \& Engka, D. (2014). Analisis Belanja Daerah dan Faktor-Faktor Yang Mempengaruhinya di Provinsi Sulawesi Utara. Fakultas Ekonomi Dan Bisnis, Universitas Sam Ratulangi Manado, 14(3), 1-12.

[12]. Hapid, H., Halim, M., \& Wulandari, Y. (2015). Pengaruh Dana Alokasi Khusus, Dana Bagi Hasil Dan Dana Alokasi Umum Terhadap Anggaran Pendapatan Dan Belanja Daerah Kabupaten Luwu. Jurnal Ekonomi Pembangunan STIE Muhammadiyah Palopo, 2(1), 1-7.

[13]. Herlina, E. (2014). Faktor-Faktor Yang Mempengaruhi Belanja Daerah Serta Dampaknya Terhadap Produk Domestik Regional Bruto Kabupaten Berau. Journal of Innovation in Business and Economics, $4(1), 25-44$.

[14]. Koranti, K., Kencanawati, M. S., \& Sagita, E. D. (2015). Analysis of Determinant Regional Expenditure Allocation In The Autonomy Era In Sumatra. 1st Unnes International Conference on Research Inovation Dan Commercialitation for Better Life 2015, 119-123.

[15]. Laksono, B. B., \& Subowo. (2014). Pengaruh Pajak Daerah, Retribusi Daerah, DAU Dan DAK Terhadap Belanja Daerah. Accounting Analysis Journal, 3(4), 457-465.

[16]. Mulyati, S., \& Yusriadi. (2017). Dana Bagi Hasil Dan Dana Alokasi Umum Terhadap Belanja Daerah Padaa Provinsi Aceh. Agregat: Jurnal Ekonomi Dan Bisnis, 1(2), 211-220.

[17]. Undang-Undang Repubik Indonesia Nomor 23 Tahun 2014 tentang Pemerintahan Daerah, (2014).

[18]. Rahmawati, L. A., \& Suryono, B. (2015). Flypaper Effect Dana Alokasi Umum Dan Pendapatan Asli Daerah Terhadap Belanja Daerah. Jurnal Ilmu \& Riset Akuntansi, 4(9), 59-70.

[19]. Rahmawati, M., \& Fajar, C. M. (2017). Pengaruh Pendapatan Asli Daerah Dan Dana Perimbangan Terhadap Belanja Daerah Kota Bandung. Jurnal Kajian Akuntansi, 1(1), 63-76.

[20]. Rusdianto, U. (2013). CSR Communications A Framework for PR Practitioners (Pertama). Graha Ilmu.

[21]. Sanusi, A., \& Yusuf, M. (2018). Pengaruh Pendapatan Asli Daerah, Produk Domestik Reginal Bruto, Jumlah Penduduk, Indeks Pembangunan Manusia, Pertumbuhan Ekonomi Terhadap Belanja Daerah di Sumatera Utara Tahun 2013-2015. Kajian Ekonomi Dan Kebijakan Publik, 3(1), 1689-1699.

[22]. Sari, R. P., \& Indrajaya, I. G. B. (2014). Pengaruh Pendapatan Asli Daerah (PAD) Dan Dana Perimbangan Terhadap Alokasi Belanja Daerah Kabupaten Badung. E- Jurnal EP Unud, 3(9), 420-427.

[23]. Sasana, H. (2011). Analisis determinan belanja daerah di kabupaten/kota Provinsi Jawa Barat dalam era otonomi dan desentralisasi fiskal. Jurnal Bisnis Dan Ekonomi (JBE), 18(1), 46-58.

[24]. Simanjuntak, A., \& Ginting, M.C. (2019). Pengaruh pajak daerah, distribusi daerah, dana alokasi umum, dan dana alokasi khusus terhadap belanja daerah. Jurnal manajemen, 5(2), 183-194

[25]. Untung, J., Widyaastuti, T., \& Suyanto. (2017). Pengaruh Pendapatan Asli Daerah, Dana Alokasi Umum, Dana Alokasi Khusus, terhadap Belanja Daerah dan Dana Bagi Hasil sebagai Pemoderasi Pemerintah Kabupaten / Kotadi Provinsi Jawabarat Priode Tahun 2010-2014. Jurnal Ilmiah WIDYA Ekonomika, 1(2), 1-7.

[26]. Wahyuni, S. E., \& Supheni, I. (2017). Flypaper Effect Pada Dana Alokasi Umum (DAU) Dan Pendapatan Asli Daerah (PAD) Terhadap Belanja Daerah Di Kabupaten Nganjuk. Akuntansi Dewantara, 1(2), 188-200. 